\title{
Ozzie Kids Flee the Garden of Delight: Reconfigurations of Childhood in Australian Children's Fictions
}

\author{
Beverley Pennell
}

\begin{abstract}
... the root cause of much present concern and angst about childhood is that a public discourse which argues that children are persons with rights to a degree of autonomy is at odds with the remnants of the romantic view that the right of the child is to be a child. The implication of the first is a fusing of the worlds of the adult and the child, and of the second the maintenance of separation.
\end{abstract}

(Cunningham 1995, p.190)

$\mathrm{L}$ ate twentieth-century Australian children's fictions have made significant contributions to the cultural processes transforming the Western conceptualisation of an idealised childhood which occurs in a space separate from adulthood (Cunningham 1995, pp.36-7). The reconfigurations of childhood represented in literary fictions mesh with the patterns that emerge in the research findings from other scholarly fields to suggest that the boundary separating childhood from adulthood is being dismantled (Franklin 2002, p.17; Zipes 2002, p.viii). For instance, in historiography, Hugh Cunningham's Children and Childhood in Western Society Since 1500 (1995) examines the transformations of both the lived experiences and the conceptualisations of childhood through to the fin de siècle. Cunningham argues that when early twentieth century reformers envisioned 'the century of the child', their aim was "to map out a territory called "childhood", and put in place frontier posts which would prevent too early an escape from what was seen as desirably a garden of delight' (1995, p.164). Cunningham argues that this reconfiguration of 'child' and 'childhood' moves away from idealised and monologic conceptualisations which typically employ tropes that represent the child as either a plant to be cultivated or a pampered pet (1995, p.188; also Aronson et al 1996, pp.194-200 and Franklin 2002, p.17). Both tropes imply a hierarchical relationship between adults and children where adults hold the power and have full responsibility for children until they reach 'maturity'. Children's developing competencies are not acknowledged.

Cunningham (1995) concludes that the mid-twentieth century perspective of Philippe Ariès' Centuries of Child- hood (1962) quite correctly traced a history of childhood that showed 'an increasing differentiation between adults and children' from the seventeenth century onwards. He finds that at that time Ariès' rhetoric of childhood as a period of 'quarantine' from adults and the public sphere is justified (1962, p.397). However from the perspective of the millennium, Cunningham sees this trend of separation as reversing and that there is 'an increasing disjuncture between the romantic ideal and the lived reality' of children's experiences (1995, pp.189-90). Some aspects of this reversal result from changes in the life patterns of adults while others derive from socio-cultural shifts that impact on family life. Of equal importance, Cunningham argues, is that children themselves 'have begun to break out of the ghetto of dependency in home and school to which they had been assigned' (pp.188-9; also Kociumbas 1997, p.194 and pp. 230-31).

Jan Kociumbas's historiography Australian Childhood: A History (1997), concurs with Cunningham's views about trends that are fusing the worlds of adults and children. As we saw above, Cunningham employs the colonial tropes - 'territory' and 'frontier posts' - to describe how childhood was viewed in the early twentieth century. Kociumbas uses the postcolonial trope of 'decolonisation' to describe shifts in paradigms of childhood in Australia after World War II (1997, pp.194-215). She uses the term's denotation to describe the changes in the lived experiences of Australian girls and boys and the term's connotations to map the influence of reconceptualisations of childhood on Australian sociological, educational and cultural policies. These shifting understandings of childhood are significant because they shape public policies that impact materially upon family life, income levels, schooling and the public/private boundary that (de)limits the life experiences of children (also Cunningham 1998, p.1198). This paper focuses on the ways that narratives and literary discourse also represent the struggle to decolonise the space of childhood. The fin de siècle representations of child subjectivities and adult/child relations are vastly different from those found in mid-century fictions like Joan Phipson's Good Luck to the Rider (1953), Patricia Wrightson's The Crooked Snake (1955) or Nan Chauncy's Tiger in the Bush (1957). Wrightson's and Phipson's fictions represent children and 
adults patrolling the borders of separate territories.

Understandably perhaps, attempts to subvert separatist conceptualisations of childhood-originating from 17th century views like those of John Locke, Jean Jacques Rousseau, religious writers like the Wesleys - cause alarm because they change the power relations between adults and children. Little wonder that Cunningham's review of childhood historiographies wryly describes his field as 'lively' (1998, p. 1195). In Bringing Human Rights to Life (1993) the Australian legal scholar Peter Bailey concurs with Cunningham's (1995) argument that the reconceptualisation of the international community's definition of childhood was formalised by the United Nations' International Convention on the Rights of the Child (1989). This convention received swift and widespread endorsement. Cunningham argues that the Convention provides 'not only for the protection of the child but also for its right to be heard in any decision that may affect her or his life.' (p.185). Article 5 of the Convention enjoins all lawful authorities with duty of care for a child to assist her or him in 'the exercise' of her or his rights. It also requires that both the state and parents acknowledge the "evolving capacities' of the child (1993, pp.151-66).

While many regard the 'demythification and democratization' of childhood (Metcalf 1997,p.50) as an issue of social justice, others oppose such moves. Advocacy of children escaping from the 'garden of delight' — where 'the right of the child is to be a child' - threatens the concept of a 'proper childhood' of dependence, innocence (especially sexual), play and education (Cunningham 1995, p.188; Franklin 2002, p.17). Both the 'angst' mentioned in the epigraph, and the assumptions of the 'maintenance of separation' are evident in some criticism in the field of children's literature. Mary Galbraith's paper, 'Hear My Cry: A Manifesto for an Emancipatory Childhood Studies Approach to Children's Literature' (2001) is one instance of this. For Galbraith childhood is a fixed signifier, as the phrase 'the truth of childhood' indicates (2001, p.191). In my view this reifies and naturalises a homogeneous view of childhood. Galbraith employs Habermas (1968) and de Mause $(1974)^{1}$ to frame her argument about the contemporary social structures impinging upon children and I think newer research is available that leads to different understanding of social transformations. The paper certainly demonstrates that in discussions of childhood - theory and practice - it is necessary to acknowledge the historicity of conceptualisations of childhood and also their socio-cultural specificity (see Cunningham 1998, p.1198; Franklin 2002, p.17).

All movements for social justice, including those concerned with the rights of children, must face issues of structural power, whether it is a group - an ethnic or religious minority - or an individual subject deemed subaltern because of race, gender, sexuality, disability or age. Structures of social life that legitimate certain hierarchies of people as 'natural' disempower and (dis)place such subaltern subjects (Bourdieu 2001, p.102-6). As with the possibility of narrative reconfigurations of gender relations (Bourdieu 2001, pp.84-5; Pennell 2002) so too with the discursive reconfiguration of adult/child relations, attention must be paid to representing the relational dimension of adult/child interactions. Effective power shifts are achieved by altering the structures of relations and not just by subjective change on the part of dominated individuals and groups. Negotiating personal agency and democratic interpersonal connections - intersubjectivity - is the significant challenge.

Transformative fictions - those that disrupt metanarratives of adult/child separation - take up this challenge and represent the operation of power as the major factor to be addressed in reconfiguring adult/child interactions. Such narratives represent transformed adult/children structures of power relations by foregrounding the relational dimension of child interactions with adults as significant in two ways: first, in the subjectivity of the main child participant(s) and second by making it central to the primary level story-line. Narrative strategies such as dialogue are used to represent child subjects with an evolving capacity for democratic intersubjective relations with adults. Some adult participants regard children as competent subjects and acknowledge the need for mutuality and reciprocity in relationships with them. Child subjects develop strategies for dealing with adults whose attempts at intersubjective relations assume a deficit model of childhood. Importantly the strategies are not just subjective adjustments but practical behaviours that resist adult psychological and physical manipula- 
tion. Successful fictions typically offer a broad range of participants who are represented in complex matrices of social values and practices that offer a double articulation: that is, representations of the 'normal' or traditional social structures as well as the envisioned new possibilities. The agential effect of the narrative is strengthened if there are multiple implied reader positions and if readers are assumed to be both boys and girls in an ethnically and culturally diverse community.

Joanne Horniman's Sand Monkeys uses postmodernist literary strategies to enter the debate about contemporary conceptualisation of childhood. This fiction suggests the fluidity of the meaning of 'family' in contemporary sociocultural context or of representing Australian childhood experience as homogeneous. Horniman's fictions typically privilege alternative lifestyles and non-traditional domestic patterns as spatio-temporal frameworks. Her fictions undermine traditional idealised arrangements such as nuclear families, often representing them as lonely and isolating (p.26). There is an advocacy of more open, inclusive, community-oriented domestic organisations that acknowledge the evolving cognitive and practical capacities of children. The limited agency of children is thematically represented in Sand Monkeys by the emotional and social disruption that the children experience because of parental decisions about moving the family home whether locally, intra or inter-state (p.1,11,14). Max's family moves a short distance, only five streets, to return to a group home where the family had lived when he was a toddler. Here he was one of a pair of 'sand monkeys' photographed in a backyard sand pit. Discovering the other sand monkey's identity is one of the reader's challenges. Although Max is not informed, his mother, Monica, wants him to know the other sand monkey, Emma, whose devoted father took her away from the group home. Emma remembers losing her surrogate brother and mother-Max and his mother-but Max remains oblivious to their childhood connection for most of the fiction.

The reader is told of the family's move in an embedded text that opens the fiction, a letter that Max writes to his friend Socrates whose parents have recently relocated him to Brisbane (p.1). Sixteen-year old Max experiences a sense of oppression as the move seems a pointless exercise (p.8).
While his parents have an ulterior motive for the move that they believe is in Max's best interests, the primary storyline represents secrecy as a poor intersubjective strategy in relationships between children or adults. Max's parents, Monica and Brian, return to the inner city terrace house that is 'really two houses side-by-side' in Sydney, 'One is a children's house, and the other is an adult house' (p.1) and it is 'a kind of shared household' (p.36). This alternative domestic arrangement is given historical legitimacy when Max tells his intrigued friend Olivia that it has 'been here like this for years' and that he and his parents first lived there when he was only a baby (p.36).

In Sand Monkeys the postmodernist strategy of using metafictive nomenclature for the main participants foregrounds the fiction's concern with the reconceptualisation of childhood. The main participant is named for that most (in)famous fictive child participant, Max, in Maurice Sendak's Where the Wild Things Are (1963), the canonical but controversial 1960s picture book. If the reader misses this allusion at first, it becomes an explicit intertextual link later in the fiction (p.106). Readers are then alerted to the fact that Max's peers', Emma and Olivia, also have their literary forebears and that they offer contemporary representations of their antecedents' youthful foibles and dilemmas. ${ }^{2}$ Of Where the Wild Things Are Jane Doonan writes that it was responsible for 'provoking a major debate about the content of children's books in the nineteen-sixties' (2001, p.751) as it 'was thoroughly subversive in depicting behavior and expressing feelings not generally approved of by adults' as appropriate fictive representations of child subjectivity (2001, p.752). Max is naughty and his punishment is 'time out' in his bedroom. In his confinement, he becomes the 'king of all the wild things', as Emma comments to the Max in Sand Monkeys (p.6). But after his time-out 'on his own terms, he returns to the real world, sleepy, hungry and at peace with himself' (Doonan 2001, p.752) so that he is once again contained in his family's regulatory social structure. Significantly in Sand Monkeys Max has chosen this name for himself. The implication is that the wildness he experiences is frustration at the loneliness, boredom and restraint of the traditional nuclear household where even the presence of siblings is increasingly unlikely. Only after his decision to live independently from his parents does he decide to return to his former name. In closure he subverts 
the traditional paradigms of familial ties and dependence and asserts his autonomy.

Unlike Sendak's Max, Horniman's Max flees the family home: when Monica and Brian decide to leave the shared household and return to their own private house, he decides to stay. He wants release from the restrictions and isolation of the traditional nuclear family household in order to maintain his connections with the people of differing ages and interests in the shared household. He enjoys the company of younger children who live there believing that he experiences 'what it was like to have a sibling' (p.48). As well he has access to numerous adults with their disparate social, political, intellectual and artistic pursuits. In Max we see the literary representation of Cunningham's claim that in the late twentieth century 'children have demanded and received an earlier access to the adult world; they have not been willing to accept the attempt to prolong childhood to the late teenage years' and this is a return to the historical norm of childhood ending at about fourteen (1995, p.185).

That Sand Monkeys is concerned with reconceptualisations of childhood is explicit in the extradiegetic level of narration in the description of the spatial framework which is a part of the narrative's orientation. Another significant postmodernist technique used in Sand Monkeys is the inscribed narrator who draws attention to the linguistic and fictive nature of what is being read. The story of the shared household then moves to the oddity of the houses wearing labels - 'Children', Anarchy' and 'DOORWAY' - and the penumbra of associations for each of these labels cues readers to the symbolic dimensions of the description. If the reader misses the cues here, this level of meaning is retrospectively understood when the spatial framework becomes part of another embedded text, a dialogue between Max and Olivia (pp.36-7). Olivia's curiosity about the household's organisation, its members and the architecture leads to her offering information about the wooden carvings around the interconnecting door between the two houses.

The symbolism inherent in the description of the houses offers a schematic representation of traditional views of childhood. These are constructed to allow their subversion as the story lines develop. Here the adjacent houses suggest the explicit boundaries that traditionally separate the space of the child and the adult:

\begin{abstract}
The house called Children squatted slap up against the big, two-storeyed terrace called Anarchy. It was much smaller than Anarchy: narrower, and without an upstairs. They stood in a pleasant tree-filled street in inner Sydney that ran between two busy roads.
\end{abstract}

The houses looked separate, and once they had been, but a door had been made in their common wall. The door was in the living-room of the children's house and led into the adult house in the hallway just before the stairs. A thick wooden beam had been placed at the top of the doorway to support the brick, and two thick wooden posts served as uprights at each side. The beam and posts had been carved in relief with a pattern of large triangles. Someone had written the word DOORWAY on the wall above the door on the children's side.

The front door lock of Children stuck: you had to jiggle the key to get it to open, until it suddenly swung inward with ease. And then the lock didn't like to give up the key without a struggle, so that by the time you'd managed to wrest it away you felt as though you'd done battle. It was typical that it never occurred to anyone simply to fix the lock. (p.3)

The oppositional discourses of childhood and adulthood are signified by the fact that the houses still appear to be separate and were at some tine in the past. The advocacy of separation of the child occurs from the late seventeenth century in the writing of John Locke, Jean Jacques Rousseau and the Puritans, although each of these conceptualisations intends different educative purposes and processes for its proposal of a separate childhood space (Cunningham 1995, 62-5). In these older models the child is always deficient, incompetent and limited and so is denied autonomy and participation in social life. Significantly in Sand Monkeys the children's space is labelled in an explicit way that suggests its uncomplicated, unitary meaning. This reductive understanding is reconfigured in the story-lines of all the child participants in the fiction. The space in Children is 'much smaller' than that of the adults and the discourse 
represents it as being more confined and less elegant because it 'squatted' next to the adult house. The implications of 'narrower, and without an upstairs' are of the regulation and surveillance to which children are subject and the general sense of childhood as a deficient state. The phrase 'just before the stairs' especially suggests that choices and opportunities and autonomy only come after exiting childhood and ascending into maturity. The adult space being labelled 'Anarchy' connotes the heterogeneous and contested nature that is legitimate in adults who are implicitly powerful and agential. Max later tells Olivia that the word does not mean 'chaos' or 'a bold social experiment', in the context of this household, but rather youthful idealism (p.36).

Despite their differences, the houses have "their common wall' and a doorway has been created. The doorway, as used in the second paragraph above, is a conventional motif for access, opportunity and demystification. Here of course the word 'DOORWAY' functions metonymically to suggest the need for children to find the door, the entry into adulthood. In the dialogue between Max and Olivia, mentioned above, the doorway is foregrounded and the territory of childhood is marked by aesthetically appealing frontier posts. These posts are substantial and not meant to be removed as the repetition of the word 'thick' suggests but 'The beam and posts had been carved in relief with a pattern of large triangles'. The posts of the doorway function in the metadiegetic narration as an intertextual link in the secondary story level. Olivia, who has been to Paris and seen the carved entry way to the additional studio room that Brancusi built when his first studio was full, recognises the ornamental style as imitative of Brancusi (p.37). Brancusi's Romantic inclination with regard to childhood is well known from his statement that 'When we are no longer children we are already dead'. The fact that the artistic façade is on the children's side reminds the reader of the Romantic view of childhood. Cunningham argues that Romanticism's influence was on the conceptualisation of childhood rather than on child-rearing practices (1995, p.77). Rather than a deficit model of the child, Romanticism constructs childhood as the best time of life and ideally as a time of happiness with special qualities and attributes that make it superior to adulthood. It argues that we must keep this time alive within us so that childhood is a 'spring for the whole of life' (1995, p.73). The child is seen as 'a force of innate goodness which could rescue embittered adults', since 'at its heart was a reverence for, and a sanctification of childhood' (1995, p.74). The secondary level story-lines in Sand Monkeys represent the inaccuracy of these traditional sentimental views of childhood. The stories of Emma's disrupted childhood (pp.14, 64) and Sunny's separation from his father (p.62) give the lie to the Romantic childhood.

The individual's negotiations with the discourses of childhood and the experiences of domestic life are symbolically represented in the third paragraph above, where the door lock and key to Children are described. Conventionally keys symbolise power, mastery and dominion but this is not the case with the house because the door lock is so poorly maintained that even having the key is no guarantee of easy access: 'the lock didn't like to give up the key without a struggle, ... '. The inference is that the inevitable passing from the state of childhood into adulthood occurs with more rather than less pain but as the transition is inevitable and we move on, so 'it never occurred to anyone simply to fix the lock'. Children remain separate, in a place of 'quarantine' or for a privileged few, in 'a garden of delight'. When Max escapes the territory of childhood he resumes his name, Sasha/Alexander (the Great) as he no longer accepts his agency as contingent upon parental decisions. The need for structural change is argued in 'It was typical that it never occurred to anyone simply to fix the lock' but attempting to open the door and jiggling the keys is what matters. Differences between children are foregrounded because Emma insists that she wants to relocate yet again with her father. Max urges her to stay in the shared household because having a sibling has proved emotionally satisfying as well as expanded his intersubjective capacities.

Sand Monkeys problematises the separation of childhood from adulthood as a form of oppression in familial relations: narrative discussions focus on concepts of childhood as they relate to the care and protection of children in the home. Hirsch's Hazel Green is also a transformative fiction because of its concern with social inclusivity. It shifts the discussion of childhood to issues of the child's participation in the community: child/adult relations move in the public 
sphere, to the social structures, policies and practices of Hazel's apartment block. In the field of law and the child Bob Franklin's 'Children's Rights and Media Wrongs' argues that while acknowledgement of the rights of the child according to the United Nations Convention on the Rights of the Child (1989) are accepted as unproblematic in terms of the rights to 'provision' and 'protection' the third right, to 'participation' in society, remains virtually unrealised (2002, p.20). That is, there is usually neither opportunity for children to be agential in their relationships with adults nor to participate in society's public domain.

In the Hazel Green trilogy, Hazel Green and many adult participants are represented as understanding that child subjects have evolving capacities for democratic intersubjective relations with adults and so the ghettoisation of children is actively resisted. The idea that lived experiences and personal attributes can be divided up between different periods of life is exposed as a myth. The separation between the adult/child worlds disappears in many social contexts however it becomes clear that states of 'quarantine' exist in the community for others beside children: for the sick, the disabled, the elderly, the migrant, as well as for children (2001, p.240). Attempts to maintain the fiction of adult/child separation, mean that adult behaviors and assumptions are ironised. Something 's Fishy Hazel Green (2000) foregrounds how people of all ages continually have more to learn about one another and their competencies (pp.10, 11, 13, 14). For instance, the theft of some magnificent lobsters from Mr Petrusca, the fishmonger, turns out to be a practical joke between two elderly friends. Hazel reflects:

What was going on? Did adults really do things like that-play pranks on each other and feel foolish when they didn't work? That was the kind of thing she did with her friends! Adults weren't meant to do it. And did they really have competitions like that, to get the biggest lobster or write the cleverest codes? And then there was Mr Petrusca, of course, who had spent his whole life pretending to be able to do something that he couldn 't. That was another thing adults were not supposed to do ... She was starting to feel more grown up than a number of the so-called grown-ups around her. (p.180)

This paragraph repeats and expands Hazel's earlier amaze- ment at Mr Petrusca's 'having to pretend all the time!' (p.98) because he is unable to read and has spent his adult life 'pretending' that he can. In both examples the dissolution of the adult/child boundary does not demonise adults as typically happens in the fictions of the 1970s and 80s (Metcalf 1997, p.52). Rather, it ironises the fallacy of ageist rhetoric. The pejorative implications of 'childish' can be appropriate to people of all ages (p.177). He is a successful fishmonger and hides the fact that his literacy skills are limited to necessary survival tactics within his business world. Hazel discovers Mr Petrusca's secret accidentally and sees that it is this 'shame' that causes his severe depression (pp.92-3). As Marcus Bunn comments in Have Courage, Hazel Green, this knowledge places her in a position of absolute trust with an adult's self esteem and tests her loyalty (2001, pp.177). The narrative tracks how adult concerns and knowledge become available to children; 'innocence' connotes 'ignorance' and limits subjectivity, while experience leads to agency and empowerment.

The social competence and intellectual capacities of children are represented as being as various as those of adults. Suppression of precocity is represented as an act of domination: 'To put it bluntly, Hazel Green wasn't the kind of person whom other people ignore. It wasn't her fault, that's just how she was ... Everyone had an opinion about her' (p.75). She is a girl with bright ideas and leadership skills who attempts to foster cooperation without recourse to the operations of hierarchy in the manner of her rival, Leon Davis. The narrator acknowledges the range of skills all children display and Hazel knows that many have capacities that she has not yet had the opportunity to acquire. Her newest friend, Yakov, already possesses mathematical knowledge and skills that defy most adults in the community (p.147). Hazel believes that children should think for themselves as soon as they are able. She condemns Leon Davis because she knows that his opinions are second-hand (2000,p.31;2001,p.174) and Marcus, too, for his lack of everyday competence because his mother will not let him undertake domestic tasks - he is not allowed to boil water let alone cook a lobster (2000, p. 22). In Have Courage, Hazel Green, Marcus's concern about doing only those things that adults allow (2001, p.139) is seen by Hazel as one that limits children to experiences such as visiting antique markets at the Rum Warehouse (2000, 
p.120-3) or attending fine art auctions at 'Motheby's and Mistie's' (2001, p.146). It also limits agency unnecessarily when complex situations, 'matters of principle' are the concern (2001, p.55): for instance, the hypocrisy and lies of powerful 'respectable' adults, like the lawyer Mr Davis, with regard to ethnic prejudice (p.189). The Hazel Green trilogy represents the evolving capacities of the child as the thematic issues that involve Hazel become more complex in each book: in Hazel Green Hazel names Mr Volio's new Frogg Day pastry the 'Chocolate Dipper'(pp.16-7) whereas in Have Courage, Hazel Green she names and confronts racism directed at the Moodey Building's caretaker, Mr Egozian and at Yakov by his school peers (pp.51-3). Parallel stories - an exaggerated mise en abyme - for child and adult participants successfully subvert the notion of adult/child separation as 'natural'.

The Hazel Green trilogy reconfigures adult/child structures of power relations because the relational dimension of child interactions with adults is central to the primary level storyline. Hazel Green capitalises on contemporary Australian socio-cultural moments of national celebrations at the fin de siècle and simultaneously addresses the predicament of the disenfranchisement of the nation's children. The approach of the new millennium coincided with a number of symbolic national events - the celebration of the centenary of the Federation of the Australian colonies in 2002, the Olympic Games held in Sydney in 2000, the referendum on an Australian republic in 1999-so that concepts and critiques of 'nation' and 'national identity' are issues of keen debate. In Hazel Green, then, Hazel decides to be proactive in having children enter the public domain by becoming part of the celebrations of the national day:

\section{Hazel thought about all the Frogg Day marches she had seen: the colour and noise and excitement. The crowds were so thick you could barely slip through them to get to the front ... And until today it had never occurred to Hazel that anything was missing.}

But something was missing, something important. Children marching on Frogg Day? And why not? (p.20)

The name of the national day, Frogg Day, suggests a certain levity in the narrator's attitude to national celebrations: 'visi- tors from abroad, especially ones who couldn't spell, often wondered why the city made such a fuss over slimy little animals who jumped around. But it wasn't about frogs at all' (p.21). Indeed, it is about Victor Frogg, the 'Father of the Nation' (p.82), 'who had brought peace again. And Union Day was proclaimed to celebrate it' (p.21). As Victor Frogg was born in the Moodey Building, the local celebration is especially significant and is even called Frogg Day rather than Union Day. Mrs Gluck, a realist fairy godmother, who provides intellectual rather than material gifts, the Volios and the Coughlins encourage Hazel's decision to have the children participate in the parade. Nevertheless Hazel and Leon need courage to face the 'terrifying Mr Winkel' to seek permission to submit a design to the procession committee (p.49). Fortunately another committee member, $\mathrm{Mr} \mathrm{McCulloch}$ is present when the children make their request and he mounts an argument about fairness that Mr Winkel cannot discount (p.47). Even so, he decrees that the children cannot simply join the adult contingent but must produce 'a separate display, something of their own', and 'something interesting and exciting, to show your respect for the memory of Victor Frogg' (p.47). The tenor of the dialogue represents $\mathrm{Mr}$ Winkel as sure that the children lack the organisational capacity, the creativity, intelligence and skills to produce a display that will meet adult standards. The children's idea for the construction of a miniature replica of the Moodey Building proves him wrong. Parents and adult community members support the project by providing space, materials and teaching some necessary skills but they do not interfere in the children's execution of the project. Even the problem of the model's stability is discovered by a child, the mathematically-gifted Yakov, and the necessary alterations are carried out by the children. The shift in power differential in adult-child relationships is the focus as the children come out of quarantine to be seen and heard.

The narrative reconfigurations of adult/child intersubjectivity are a key strategy employed in the Hazel Green trilogy to undermine assumptions of separation. The 'good' child is no longer the one who is dependent, biddable, submissive or naive. Hazel has a healthy scepticism with regard to social structures because her experience is that 'Rules were often ridiculous and new rules were often more ridiculous than the rest' (2001, p.20). Some adults confirm Hazel's 
scepticism and encourage her to act courageously on a 'matter of principle'. Mrs Gluck tells Hazel that 'sometimes you have to go against the rules to prove your point' but that you must be prepared to accept the consequences of going outside the law (p.189). Children are represented as being both as wonderful and as despicable as adults: attributes such as integrity, compassion, responsibility, loyalty are not indicated by chronological age nor are they allocated between oppositional states of 'childhood' and 'adulthood'. Isolation and prejudice, fun and celebration, nonsense and seriousness are experienced by all. Hazel experiences democratic intersubjective relationships in the Volios' bakery shop and Mrs Gluck's florist shop where mutuality and reciprocity are valued and where 'a fusing of the worlds of the adult and the child' occurs (2000, pp.54$5)$. The competence of the child subject is confirmed and respect is given to the autonomous decisions made by the child, like finding out how to help an adult learn to read (2000, pp.198-9).

These fictive child subjects also develop strategies for dealing with adults who assume a monologic and deficit model of childhood subjectivity. Importantly the strategies are not just subjective adjustments but have practical outcomes. Hazel is represented as a master at interpreting how adults position her, and other children, and at deliberately undermining or confounding their expectations. Mr Murray the rival baker to Mr Volio (who is in fact an expert bread-maker, rather than pastry-cook like $\mathrm{Mr}$ Volio) imagines that Hazel can be duped. He makes the mistake of patronising her when 'he patted Hazel on the head, as if she were just a little girl who shouldn't worry about the things that grown-ups do' and Hazel ends their conversation, because 'They had finished their talk. Mr Murray just didn't realize it' (p.67). She is aware of being positioned as a child, as a girl, as disempowered by $\mathrm{Mr}$ Murray and acts upon the knowledge by removing herself from his shop. Mr Winkel is more subtle than Mr Murray but no more successful:

\section{'Hazel Green, you are quite as rude as I've heard!' cried Mr Winkel, while Mr McCulloch almost fell off the stool.}

Hazel didn't know what this meant because she had no idea what he had been told.
'Children don't march on Frogg Day, 'he said, as if that were that.

'They did, 'said Hazel.

'That was years ago. Twenty years ago. Before I became head of the organizing committee.'

'Mr Winkel,' said Hazel, 'when did you become head of the organizing committee?'

'Twenty years ago.'

Hazel nodded. She was beginning to understand... (p.45)

Humour is again a hallmark of the text and the sophisticated literary discourse teaches children about reading beyond the single strand narrative. The narrator plays games overtly with the reader; Hazel is often in an estranged subject position herself and the reader is positioned to observe her estranged position as on this occasion. The reader is alerted to the assumption of authority in Mr Winkel's tone in 'as if that were that'. The unsatisfactory nature of such a dictatorial assumption is highlighted by the use of 'as if' which models discourse analysis, identifying and resisting subjection. But the next step, as with Mr Murray, is to enact the refusal of subjection and intimidation. This time it is by continuing the dialogue to reveal Mr Winkel's lack of authority for his decrees (pp.46-8). The relational dimension of interactions with adults is discursively constructed to represent the possibilities of decolonisation of childhood, with child participants recognising - some much earlier than others - that lived experience is no 'garden of delight'. Such a view can be held only by people unaware of the complexity of living, so that the alienated Yakov argues that life is 'an absolutely perfect drop of honey' (p.179, original emphasis). Against this, Hazel advances the view that life is 'A thick, rich, chunky, swirly mixed up soup with a great dollop of cream added just to confuse things even more' (p.178) and 'you could never tell which chunk you were going to bump into next' (p.179). It is most significant that they continue to view the world differently.

The Australian children's fictions discussed here indicate some of the ways that literary discourse takes up the challenge to reconceptualise the 'child' and 'childhood' more democratically. They demonstrate that the socio-cultural indicators of the dissolution of the boundary between 
childhood and adulthood and the fusion of the worlds of adults and children are evident in literary texts just as they are in the research undertaken in other fields implicated in childhood studies. There is a need to move forward rather than working out of old tropes and paradigms of childhood; a need to acknowledge the 'child' and 'childhood' as historically contingent social constructions; a need to challenge romantic idealisations of the child as limited, dependent and naive. These fictions suggest that many ideas operating in Australian society are in fact redundant since children are diverse and their evolving capacities are often ignored or regarded as undesirable by adults who seek to patrol the territory of childhood. These fictions encourage children to explore the discursive practices that seek to marginalise child subjects. Child subjects are represented as interrogating their positionings by adults, as well as by other children, and deciding, through more or less painful experiences, how they will respond and whether or not they will contest adult authority and disempowering social structures. The search for a monologic 'truth of childhood' seems not only doomed but also undesirable.

\section{NOTES}

1. Lloyd De Mause's The History of Childhood (1974) regards the history of childhood as a 'nightmare' (p.21). He proposes a 'psychogenic' model of history that has parent-child interactions as 'the central force for change in history' and the factor determining parental success was the 'ability to regress to the psychic age of your child'. Cunningham (1995) betrays his scepticism here: De Mause 'believed that each generation of parents was likely to be better than its predecessors, in this respect, though the mechanism which drives this evolution is not at all clear' (pp.8-9).

2. Emma, who knows she has been named after the feminist anarchist Emma Goldman (59), nevertheless must learn like Jane Austen's Emma that 'The fantasies you weave around people can burden them and hurt you' (p.107). Max writes to Socrates that he better not trifle with Emma 'Because although she is not my sister, she is, sort of' (p.120). Olivia, economically privileged, world traveller, derives from Shakespeare's duchess in Twelfth Night even to the disruption of heterosexual norms (pp.101-3).

\section{REFERENCES}

Ariès, Philippe (1962) Centuries of Childhood. London, Cape.

Aronson, Karin and Bengt Sandlin (1996) 'The sun match boy and plant metaphors: A Swedish image of a 20th-century childhood,' in. C. Philip Hwang, Michael E. Lamb and Irving E. Sigel (eds) Images of Childhood. New Jersey, Lawrence Erlbaum Associates.

Bourdieu, Pierre (2001) Masculine Domination. Translated by Richard Nice. Cambridge, Polity Press.

Cadden, Mike (2000) 'Speaking to both children and to genre: Le Guin's ethics of audience,' The Lion and the Unicorn 24, 1: 128-142.

Cunningham, Hugh (1995) Children and Childhood in Western Society Since 1500. New York and London, Longman.

Cunningham, Hugh (1998) 'Histories of childhood', The American Historical Review 103: 1195-1208.

Davies, Bronwyn (1989) Frogs and Snails and Feminist Tales: Pre-school Children and Gender. St Leonards, Allen and Unwin.

Doonan, Jane (2001) 'Where the Wild Things Are,' in Victor Watson (ed) The Cambridge Guide to Children's Books in English. Cambridge, Cambridge University Press, pp.751-2.

Franklin, Bob (2002) 'Children's rights and media wrongs: changing representations of children and the developing rights agenda,' in Bob Franklin (ed)The New Handbook of Children's Rights: Comparative Policy and Practice. London \& New York, Routledge, pp.15-42.

Galbraith, Mary (2001) 'Hear my cry: A manifesto for an emancipatory childhood studies 
approach to children's literature.' The Lion and the Unicorn 25 (2): 187-205.

Hirsch, Odo. (1999) Hazel Green. St Leonards. Allen \& Unwin,

(2000) Something's Fishy, Hazel Green. St Leonards, Allen \& Unwin.

(2001) Have Courage, Hazel Green. St Leonards, Allen \& Unwin.

Hollindale, Peter (1997) Signs of Childness in the Children's Books. Stroud, Glos, Thimble Press.

Horniman, Joanne (1992) Sand Monkeys. Norwood, SA, Omnibus Books.

Hunt, Peter (1994) An Introduction to Children's Literature. Oxford and New York, Oxford University Press.

Kociumbas, Jan (1997) Australian Childhood: A History. St Leonards, Allen \& Unwin.

Metcalf, Eva-Marie (1997) 'The changing status of children and children's literature.' in Sandra Beckett (ed) Reflections of Change: Children's Literature Since 1945. Westport Connecticut, Greenwood Press, pp.49-56.

Nodelman, Perry (1992) The Pleasures of Children's Literature. New York and London, Longman.

Pennell, Beverley (2002) 'Redeeming masculinity at the end of the second millennium: narrative reconfigurations of masculinity in children's fiction.' in John Stephens (ed) Ways of Being Male: Representing Masculinities in Children's Literature and Film. New York, Garland, pp.55-77.

Stephens, John (2000) 'Children's literature, text and theory: What are we interested in now?' in Sue Clancy and David Gilbey (eds) Something to Crow About: New Perspectives in Literature for Young People. Wagga Wagga, Centre for Information Studies Charles Sturt University \& ACLAR, pp.1-14.
Zipes, Jack (2002) 'Series Editor's Foreword,' in John Stephens (ed) Ways of Being Male: Representing Masculinities in Children's Literature and Film. London \& New York, Routledge, p.viii.

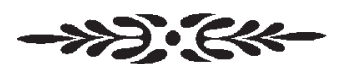

\section{BIOGRAPHICAL NOTE}

Beverley Pennell is teaching English Curriculum Studies in the School of Teacher Education at Charles Sturt University, Bathurst, NSW. 